\title{
Spatial Patterns and Characteristics of Flood Seasonality in Europe
}

\author{
Julia Hall ${ }^{1}$ and Günter Blöschl ${ }^{1}$ \\ ${ }^{1}$ Institute of Hydraulic Engineering and Water Resources Management, Technische Universität Wien, Vienna, Austria
}

\section{Supplement:}

Data Sources of the database used in this study and their respective data holders

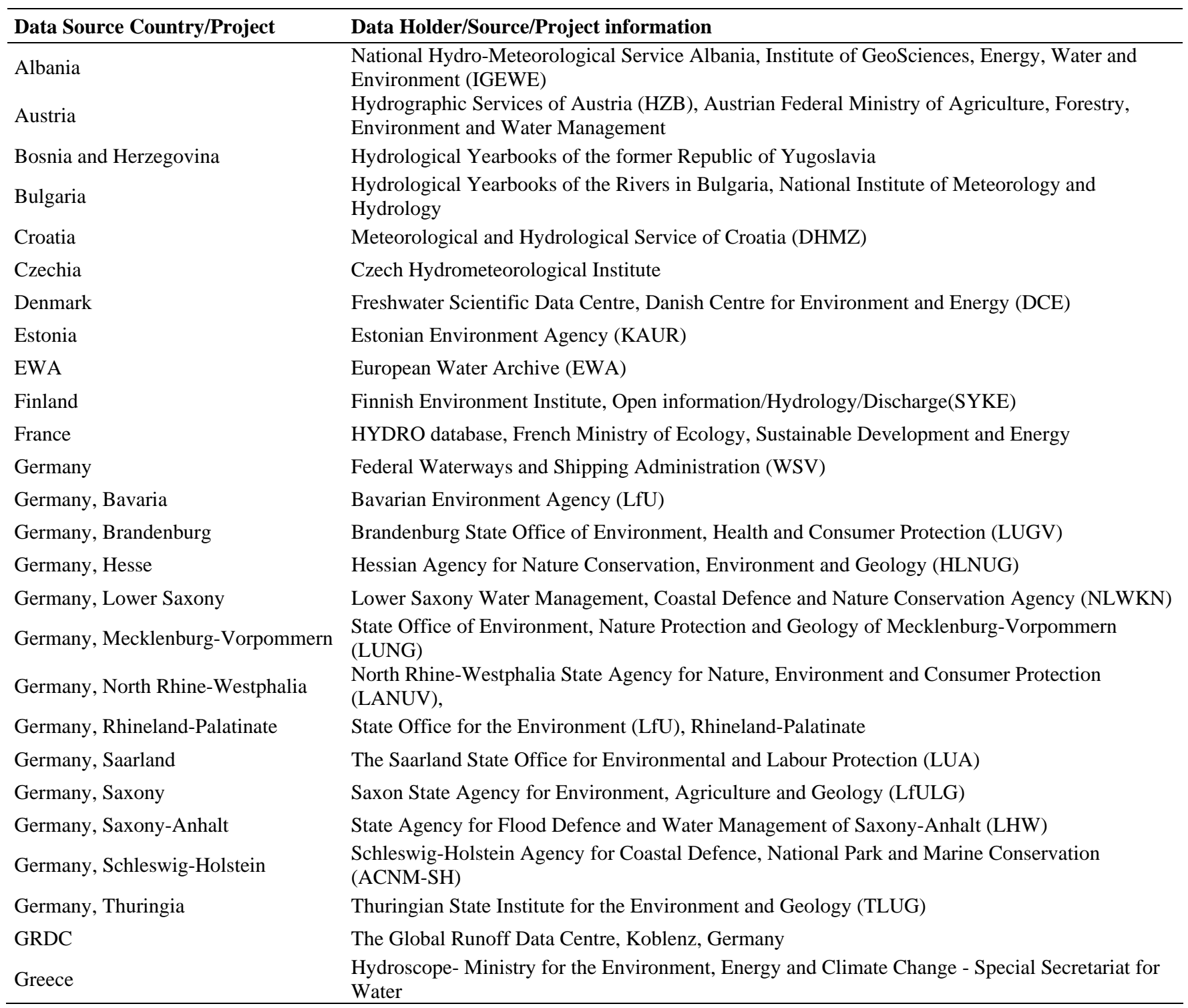




\begin{tabular}{|c|c|}
\hline Hungary & General Directorate of Water Management, Hungary \\
\hline Hungary & Lower Tisza District Water Directorate \\
\hline HYDRATE & $\begin{array}{l}\text { HYDRATE Project data base: Hydrometeorological Data Resources and Technology for Effective } \\
\text { Flash Flood Forecasting }\end{array}$ \\
\hline Ireland & Irish Environmental Protection Agency (EPA) \\
\hline Ireland & Office of Public Works (OPW) \\
\hline Italy & Former National Hydrographic Service (SIMN) \\
\hline Italy & The Italian National Institute for Environmental Protection and Research (ISPRA) \\
\hline Italy & National Research Council (CNR) \\
\hline Italy, Bolzano, South Tyrol Region & Hydrological Services, Autonomous Province of Bozen/Bolzano - South Tyrol \\
\hline Italy, Emilia-Romagna Region & Regional Agency for the Environmental Protection (ARPA), Emilia-Romagna \\
\hline Italy, Lazio \& Umbria & Bencivenga M., Calenda G. and Mancini C.P., 2001. \\
\hline Italy, Piedmont Region & Italian National Agency for Electricity (ENEL) \\
\hline Italy, Piedmont Region & Research Institute for Hydro-Geologic Protection (IRPI) \\
\hline Italy, Piedmont Region & Regional Agency for the Environmental Protection (ARPA), Piemonte \\
\hline Italy, Po Region & Basin Authority of the Po River \\
\hline Italy, Sicily Region & Water Observatory - Sicily Region \\
\hline Italy, Trentino Region & Civil Protection Department, Autonomous Province of Trento \\
\hline Italy, Tuscany Region & Regional Functional Centre of Meteo-Hydrological Monitoring, Tuscany \\
\hline Italy, Veneto Region & Regional Agency for the Environmental Protection (ARPA), Veneto \\
\hline Latvia & Latvian Environment, Geology and Meteorology Centre \\
\hline Lithuania & Lithuanian Hydrometeorological Service under the Ministry of Environment \\
\hline Netherlands & Dutch Ministry of Infrastructure and the Environment - Rijkswaterstaat \\
\hline Norway & Database Hydra II; Norwegian Water Resources and Energy Directorate (NVE) \\
\hline Poland & Institute of Meteorology and Water Management National Research Institute (IMGW-PIB) \\
\hline Portugal & $\begin{array}{l}\text { Portuguese Environmental Agency National Information System for Water Resources of Portugal } \\
\text { (SNIRH) }\end{array}$ \\
\hline Republic of Macedonia & National Hydrometeorological Service, Republic of Macedonia \\
\hline Russia & Ministry of Natural Resources and Ecology of the Russian Federation \\
\hline Russia & State Water Cadastre, State Hydrological Institute, Lomonosov Moscow State University \\
\hline Russia & AIS GMVO, Russian Federal Agency for Water Resources \\
\hline Serbia & Republic Hydrometeorological Service of Serbia (RHSS) \\
\hline Slovakia & Slovak Hydrometeorological Institute, Bratislava (SHMI) \\
\hline Slovenia & Slovenian Environment Agency (ARSO) \\
\hline Spain & $\begin{array}{l}\text { Centre for Hydrographic Studies of CEDEX, Ministry of Agriculture, Food and Environment, } \\
\text { Spain }\end{array}$ \\
\hline Sweden & Swedish Meteorological and Hydrological Institute (SMHI) \\
\hline Switzerland & Federal Office for the Environment (BAFU) \\
\hline Turkey & $\begin{array}{l}\text { General Directorate of Electrical Power Resources Survey and Development Administration } \\
\text { (EIE), Turkey }\end{array}$ \\
\hline Ukraine & Hydrological Department, Ukrainian Hydrometeorological Institute (UHMI) \\
\hline Ukraine & Hydrometeorological Institute, Odessa State Environmental University (OSENU) \\
\hline United Kingdom & UK National River Flow Archive (NRFA) \\
\hline
\end{tabular}

